\title{
Women Living with HIV/AIDS and Social Stigma in Semarang
}

\author{
Zulfa Safitri K, Amirudin, Ani Margawati \\ Department of Anthropology, Faculty of Humanities, Universitas Diponegoro \\ Jl. Prof. Soedarto, SH. Tembalang Semarang 50275 \\ Email: zulfafava@gmail.com;_Email: amdjtg@yahoo.com
}

\begin{abstract}
The issue of social stigma for PLWHA (People with HIV/AIDS) is still being a serious problem. On the other hand, it contributes to HIV/AIDS cases that have not been detected and have not been gotten special treatment yet. Social stigma, discrimination, exclusion in social life are still being a creepy consequence, especially for women living with HIV Aids. The pressure of social stigma is very influential on the perception of women living with HIV Aids, both married and unmarried to the diseases suffered. This study would like to analyze the perceptions of women living with HIV who face the social stigma that affects health behavior. The method of the study is a qualitative method with the life history approach. The techniques of collecting data are an in-depth interview, participant observation, and literature study. The informants of the study are two women living with HIV Aids already married and unmarried that assisted by Rumah Aira Semarang. The result of the study shows that PLWHA have negative perceptions related to social stigma however they try to resist the stigma so that affecting knowledge and health behavior.
\end{abstract}

Keywords: Perceptions, People Living with HIV AIDS (PLWHA), Social Stigma, Resistance, Knowledge, and Health Behavior.

\section{Introduction}

HIV/AIDS cases are already familiar in the social environment, many people living with positive HIV are not detected and get treated properly because of they are ashamed, therefore recorded case data do not reflect the actual number of cases. It related to the social stigma that they obtained. Someone who has been diagnosed with HIV/AIDS will have various indications of the HIV virus infection in a long time, comorbidities, and also the side effects caused by consumption of HIV drugs or commonly called ARV. Moreover, people living with HIV / AIDS must struggle with social problems such as stigma, depression, and cultural beliefs that can affect their quality of life (Basavaraj, 2018). Like the stigmatization of midwives to pregnant women with HIV and AIDS in Semarang City (Fitriani et al, 2013). Most private practice midwives consider that pregnant women with HIV and AIDS are women sex workers and someone who has a deviant behavior, having deadly and dangerous virus caused discrimination in differentiating services for pregnant women with HIV and AIDS with other patients. The stigma of people with HIV/AIDS can also hamper the process of seeking treatment. It occurred in another city, that is Jakarta. The case occurs in injecting positive HIV drug addicts (Ardani, 2017). The problems faced by PLWHA are not only in declining physical conditions but also in social problems, such as acceptance of negative labels and various forms of discrimination from the environment. As a result, PLWHA drug addicts in Jakarta are hampered in accessing health services. 
As we know, people with HIV/AIDS generally come from those who carry out risky behaviors such as sex workers, drug users with syringes, men or women who like same-sex, and so on. Therefore, HIV sufferers become minorities who are excluded, especially women. This article explains the perceptions of Women Living with HIV/AIDS who are already married or not related to stigma towards health behavior, who took the study location in Semarang.

\section{Method}

A qualitative research method is relevant for this study because it presents descriptive data holistically to describe the lives of women with HIV/AIDS related to social stigma. The researcher also uses the life history approach to explain the informant's life history until they infected HIV/AIDS. The life history approach can also show that not only informants internal factors of HIV/AIDS infection but also economic, educational, and socio-cultural factors. The data are collected through participant observation, it is close observation and in-depth interview with four informants women with HIV/AIDS. In addition, the researcher also uses a literature study to support data collection.

\section{Result and Discussion}

\subsection{Causing Factors of HIV/AIDS Infection}

Acquired Immunodeficiency Syndrome (AIDS) is a set of symptoms that arise due to damage the body's immune system, it occurs because of a virus pre-attacks the body namely the Human Immunodeficiency Virus (HIV). Women are among the groups that vulnerability to HIV/AIDS because their genitals are container shaped. Even so, women's vulnerability to HIV/AIDS infection is not only biological factors, but also women's social status and gender generally still lower than men, and their inability to control so that they are not infected by men (Julianto, 2002).

Based on the study that has been conducted on the four informants, they can contract HIV because of the risky behavior have done basically. The factors that cause them to behave deviant are economic factors, educational factors, and cultural factors, as well as a lack of knowledge about HIV/AIDS.

The informants in this study have positive HIV because of risky behaviors that they did not realize. Lili, Rina, Riani, and Mia are sex workers often change partners. Therefore, HIV transmission can occur when sperm, vaginal fluid, and blood from someone who has positive HIV enter the body of another person. Two of the four informants namely Riani and Mia admit to taking drugs put into the body using alternately used syringes. Another way to infect HIV is by sharing syringes with people living with HIV. Family economic limitations force them to work in order to help their parents. Moreover, the low level of education of each informant caused them to be unable to get decent jobs.

Men have more control over women in this study. Sex workers intend to carry out safe sex patterns, but when they apply they have difficulties. Customers who positioned themselves as a king feel entitled to satisfy sexual services because they spent money to pay sex workers. A difficult position makes some sex workers such as Lili, Rina and Mia forced to fulfill the desire of customers, while Riani dares to refuse firmly if there are customers who do not use a condom, but this does not apply to her boyfriend. This phenomenon illustrates how women are very exploited in terms of sexuality. The informants also admit that when they became a sex worker their knowledge about sexually transmitted diseases, especially HIV/AIDS is very lacking. 


\subsection{Social Stigma for PLWHA}

Values and norms in society are used as a standard in giving good or bad judgment, appropriate and inappropriate, to regulate behavior, to discipline including to supervise everything and even giving social sanctions. Informants, in this case, are stigmatized as a result of violating the values and norms that have embraced and used as guidelines by society to behave properly. Such as the value of religion which views free sex as bad and inappropriate as well as norms of conduct that prohibit raping, fornicating, gambling, using drugs and so on.

Lili is a young HIV/AIDS sufferer who is unmarried, she is stigmatized from some of her closest neighbors. The society no longer wants to buy merchandise sold by Lili and her mother. By the neighbors, Lili is considered able to transmit the HIV/AIDS virus through fried foods sold by her mother. Lili also gets a stigma from her schoolmates and closest friends. Lili has been insulted because she is considered naughty and careless that cannot maintain virginity.

Getting a negative judgment is also felt by Rina, she is a woman with HIV/AIDS whose status is unmarried like Lili. Another case of Lili family who always supports her recovery, the Rina family even give a stigma. Rina's brother often insults her as a sex worker and family disgrace bearer. In addition, the cruel expressions of stigma are also felt by Riani, the mother who had one child stigmatized by her closest family and neighbors. They maintain a distance if they interact with Riani because of her HIV/AIDS suffer can transmit through the air, hand touch and so on.

Mia is an informant also felt the social stigma. Previously she admitted that the risk of having a lay family about HIV/AIDS made her difficult to explain. The stigma is none other than his own family. His brother in this case often gives a stigma because he thinks that HIV/AIDS is a deadly disease. Mia even almost expelled from her own home due to illness. She is often referred to by his brother as an immoral woman because she has made promiscuity and used drugs.

\subsection{The perception and resistance of PLWHA are related to Social Stigma.}

The informants have negative perceptions for social stigma received generally. With this stigma, PLWHA are difficult to interact in the social environment. They had lost confidence in themselves to live their lives. The perception pattern of social stigma results in resistance carried out by people with HIV/AIDS to free themselves from stigma. HIV sufferers have ideas and beliefs as a way to be recognized in a particular social environment. They have basic knowledge and moral support obtained from peer support groups of fellow HIV/AIDS sufferers. It is as a basis for an individual to conducts behavior that relies on improvisation when faced the condition in the social field (Bourdieu 2010, Amirudin 2017, Amirudin 2018).

The form of resistance that actually carried out by informants, Riani and Mia, they will not hesitate to fight with violence and transmit HIV if someone gives stigma and discriminatory treatment. They just understood about the way HIV transmission from doctors and Rumah Aira after knowing that they have HIV/AIDS that the easiest transmission is through open wounds owned by people with HIV and affected by people who have negative HIV. This is used as a weapon by Riani and Mia to fight if there are people who give stigma. Unlike Riani and Mia, an informant named Lili conducts resistance by participating in socialization. Since staying at Rumah Aira, she learned that Rumah Aira's routine activities to 
socialize about HIV/AIDS became one of the media to erase the myth of stigma that has been circulating. Lili often participates in socialization as a place to express herself in the social environment so that other people do not misunderstand those who suffer HIV/AIDS like her. As a result, Lili has the courage to interact and open status in the social environment. While Rina conducts resistance by gathering with peer support groups because she knows that after suffering HIV/AIDS she is not alone even though some people give her a stigma. According to Rina peer support groups function as a tool to improve acceptance attitude and understanding, fostering self-confidence so that she has enough courage to interact and build resistance to the stigma that arises from within her. For her, the peer support group is a place to share ideas and information about ways to stay healthy to be accepted by the society, Rina conducts resistance by consuming ARV regularly and checking her condition to the doctor regularly.

\subsection{Knowledge and Behavior of PLWHA Related with Health}

Based on the study that was conducted, four informants admitted that they understand more about HIV/AIDS after suffering the disease. Medical staff provides knowledge to them relating ways of transmission and prevention methods. The ways of transmission are unsafe sexual intercourse, sharing syringes together both for injecting drug use and blood transfusions, and transmission from mother to baby during childbirth, but this can be prevented by baby's mother with consumes ARV regularly even though the chances are very small. The informants also know that HIV/AIDS can be prevented actually by having sexual intercourse only with one permanent partner who is not infected with the HIV or by using a condom and also do not use syringes simultaneously.

The informants are aware of the dangers of HIV, therefore they must always consume ARV as recommended by doctors to be able to prolong their lives. Two informants namely Rina and Lili argue that Anti Retroviral Virus/ARV is a drug used to reduce the rate of growth of the HIV virus in the body. Two other informants namely Riani and Mia said that ARV taken by PLWHA so that the body endurance is not weak and susceptible to disease. Taking ARV for people living with HIV/AIDS is a habit that they must do every day. According to the informants, the habit is carried out routinely at the same hour. The informant named Lili admitted that she has the support from Rumah Aira, which is often reminded to take ARV on time because she lives with other HIV sufferers. In addition, according to her, staying in a house makes her daily nutrition of four healthy and five perfectly fulfilled because of nursing staff always strives to care for and treat PLWHA well, so that they are not susceptible to disease. According to Lili, the pattern of her life in the house is more regular because she has to rest on time, exercises regularly but fit the portion of her body strength, and eats on time. In addition, two informants Riani and Mia who have husband admitted that they are often reminded to take ARV by their husband, besides that their husbands also support that Riani and Mia are not permitted to do heavy work so that their body condition always fit. It is different from Rina because her parents and boyfriend do not know that she has HIV, so no one pays attention to her condition except herself and her peer support group.

The informants also adopt knowledge and health behaviors that they value can improve the quality of health. Health behaviors conducted in addition to the rituals of taking ARV are based on local knowledge and their beliefs, both those obtained through peer support groups, knowledge from hereditary, Rumah Aira house, and so on. Lili often feels aches and pains in her body since being suffered from HIV/AIDS. She realized that the virus in her body can make it very fragile, especially the side effects of ARV. Therefore, Lili often overcomes the pain by asking a massage to parents, it means she gets a massage by a masseuse. According to the story of Lili from a masseuse who used to massage her, pressing and massaging the whole 
body especially at a certain point of the pain center felt will smooth the blood circulation. If the blood circulation is smooth, it will be able to circulate throughout the body in a balanced manner, so that the oxygen carried by the blood can be absorbed properly by the organs in the body. Meanwhile, Rina is accustomed to drinking traditional herbs to prevent the transmission of various diseases. She drinks herbs are almost different types every day, but she often drinks Beras Kencur and Kunir Asam, Rina argued that besides it tastes good and it is not bitter, this type of herbal drink can prevent health problems such as sore throats and canker sores. Rina also believes that if consumed regularly, it can relieve nausea and good for the stomach due to the side effects caused by ARV.

Furthermore, another informant such as Riani overcomes her disease more often than to prevent the disease. According to her, taking ARV is enough to help maintain health. Riani admitted that she often feels pain in the head. Then she treated her headache by taking panadol two tablets at once. In addition, she often diagnoses symptoms such as headache, nausea, fever as a cold. The unwell condition is believed that too much wind entering the body through the pores. Riani overcomes cold by body scraping. She often uses red onion or coin as a tool for body scraping, first by applying eucalyptus oil so that the body parts that will be scraped slippery and not hurt, then scratch the parts of the body with pieces of red onion. On the other hand, Mia is a Woman Living with HIV/AIDS who is happy go lucky about health problems. Mia's habit of maintaining her health to prevent disease is by eating vegetables frequently. She believes that a healthy body starts with nutritious food. In addition, she always suggests herself with positive thoughts to stay in good health and wellness, because the mind controls a perception. So when she is sick, the most important believes are the power of suggestion in the healing process, if she believes it will be okay and healed, the body will respond and heal itself, on the contrary, if she feels the disease is severe, anxious, and worried the body immunity will be weakened and susceptible to disease.

\section{Conclusion}

This study shows that the informants have negative perceptions related to the social stigma that they obtained. With this stigma, PLWHA are difficult to interact in the social environment. They had lost confidence in themselves to live their lives. The four informants generally gained social stigma, both from family, friends, and neighbors. The lack of understanding of HIV/AIDS makes people insult, ostracize, and are considered as if there is no existence. The perception pattern of social stigma results in resistance carried out by people with HIV/AIDS to free themselves from stigma. HIV sufferers have ideas and beliefs as a way to be recognized in a particular social environment.

They try to set aside social stigma and make it a motivation to rise up and continue to struggle to improve the quality of health in order to see people - loved ones happy. The informants tried to obey with the ARV therapy that they are taking. They also strive to keep their immune conditions awake and always eat nutritious foods. In addition to taking ARV carried out every day, PLWHA have their own tips for maintaining health in accordance with their local knowledge.

\section{Bibliography}

Amirudin. 2017. Media, Ranah dan Dinamika Permainan. Endogami: Jurnal kajian Antropologi, Vol. 1 Nomor 1 Desember 2017.

Amirudin. 2018. Antropologi Media: Agama dan Produksi Budaya di Layar Kaca. Semarang: Undip Press Semarang. 
Ardani, Irfan., Sri, Handayani. 2017. Stigma terhadap Orang dengan HIV/AIDS (ODHA) sebagai Hambatan Pencarian Pengobatan: Studi Kasus pada Pecandu Narkoba Suntik di Jakarta. Buletin Penelitan Kesehatan, Vol. 45, No. 2, Juni 2017: 81 - 88.

Basavaraj K.H., M. A. Navya., R. Rashmi. 2010. Quality of Life in HIV/AIDS. Indian Journal of Sexually Transmitted Diseases and AIDS, Vol. 31, No. 2.

Bourdieu, Pierre. 2010. Arena Produksi Kultural. Translated by Yudi Santosa.

Fitriani, Ayu., dkk. 2013. Stigmatisasi Bidan pada Ibu Hamil dengan HIV dan AIDS di Kota Semarang. Jurnal Promosi Kesehatan Indonesia, Vol. 8, No. 1, Januari 2013.

Julianto, Irwan. 2002. Jika Ia Anak Kita (AIDS dan Jurnalisme Empati). Jakarta: Penerbit Buku Kompas. 